\title{
A strategic study of the impact of invasive alien plants in the high rainfall catchments and riparian zones of South Africa on total surface water yield"
}

\author{
JDS Cullis ${ }^{*}$, AHM Görgens ${ }^{1}$ and C Marais² \\ ${ }^{1}$ Ninham Shand Consulting Services (Pty) Ltd, 81 Church Street, Cape Town 8001, South Africa \\ ${ }^{2}$ National Working for Water Programme, Department of Water Affairs \& Forestry, Private Bag X4390, Cape Town 8000, South Africa
}

\begin{abstract}
The aim of this study was to develop a methodology to determine the impact of upland (non-riparian) invasive alien plants in the high rainfall catchments and riparian areas in all catchments on the total surface water yield available in each of the water management areas of South Africa. This would enable the Department of Water Affairs and Forestry (DWAF) through its public programme Working for Water (WfW) to develop a user charge system for the clearing of invasive alien plants in South Africa. It was found that the total impact of upland invasive alien plants in the high rainfall catchments on the total surface water yield of the country, which included the yield from major dams, minor dams and run-of-river yield, was currently approximately $172 \times 10^{6} \mathrm{~m}^{3} / \mathrm{a}$ and could go up to as much as $1410 \times 10^{6} \mathrm{~m}^{3} / \mathrm{a}$ in the future. The impact varied greatly between water management areas and had the potential to reach $50 \%\left(195 \times 10^{6} \mathrm{~m}^{3} / \mathrm{a}\right)$ of registered water use in the Thukela WMA in the future if not controlled. The reduction in yield due to invasive alien plants in the riparian zone in all catchments was estimated to be approximately $523 \times 10^{6} \mathrm{~m}^{3} / \mathrm{a}$ under current conditions and this could increase to $1314 \times 10^{6} \mathrm{~m}^{3} / \mathrm{a}$ if the riparian zone was allowed to become fully invaded. The combined impact was estimated at $4 \%$ of current registered water use and could increase to $16 \%$ of registered water use in the future.
\end{abstract}

Keywords: invasive alien plants, surface water yield, South Africa

\section{Introduction}

It is well documented that invasive alien plant species (IAPs) reduce the availability of water through a reduction in mean annual runoff (MAR) and hence on water yield (Görgens and Van Wilgen, 2004). There is, however, still uncertainty about the magnitude of this impact, particularly at a national scale. Combating the spread of IAPs is becoming increasingly important as South Africa is searching for ways to augment and secure its water supply in the light of the increased cost of infrastructure development and the limited options available to introduce further supply-side measures to water augmentation. There should therefore be no question about the need to explore and implement alternative water augmentation schemes, such as through the removal of IAPs, which, as an added benefit, could contribute significantly to poverty alleviation and the development of the economy of the country and the fulfilment of obligations under the Convention on Biological Diversity.

In a recent external evaluation of the WfW Programme, it was estimated that the cost of removing all existing IAPs (excluding the impact of biological control on the spread of some species), amounts to approximately R1.6 bn. According to the Conservation of Agricultural Resources Act, the responsibility for the control of IAPs lies with the land user. However, taking into account the history of alien plant invasions in South Africa, the current land user cannot be held fully accountable for the control of IAPs. Government itself played a major role in

\# Revised paper. Originally presented at the $12^{\text {th }}$ Biennial SANCHIAS Conference held in Midrand from 5-7 September 2005.

* To whom all correspondence should be addressed.

盛 +27 21 481-2459; fax: +27 21 424-5588;

e-mail: James.Cullis@shands.co.za

Received 20 July 2006; accepted in revised form 22 November 2006. the introduction of the majority of IAPs, for reasons stretching from commercial to natural resource rehabilitation (drift-sand stabilisation) to horticultural use. In addition, with major poverty alleviation and biodiversity benefits, the question could be asked: why not recover the full cost of clearing IAPs from the government tax base?

Government already makes a substantial contribution to this process through the Expanded Public Works Programme. This contribution amounts to $\mathrm{R} 380 \mathrm{~m}$./a in the form of the current WfW activities, plus some contribution through the Working on Fire (a portion of R44 m.), Working for Wetlands (a portion of R30 m.) and Landcare Programmes. The current extent of the problem, however, is of such a nature that the above contributions through general taxes, as well as the efforts of individual land users, are simply not going to be able to prevent the spread of IAPs. Land and water users have to contribute to controlling the problem. Land users already contribute through individual clearing programmes to protect their land. What is now required is an integrated strategy for the control and management of IAPs. In order to contribute to such an integrated strategy, the aim of this study is to develop a fair mechanism to get water users to contribute to the control of IAPs, to the extent where they would get good value for money in terms of enhancing:

- The yield from dense infestations where there is a negative effect on utilisable water

- Water security by preventing further spread of IAPs that will have a negative impact on future yields.

As in the case of the land user (productive potential of land) the water user (productive potential of water) will therefore pay for the service of enhancing and securing the restoration of the natural capital base. 
With this in mind, DWAF has commenced with a strategic level investigation into the feasibility and viability of implementing a user charge, possibly as a component of the water resource management (WRM) charge, to cover the cost of clearing IAPs in the areas where they are considered to have the greatest impact; primarily in the mountain catchments areas (MCAs) and riparian areas of the country. This investigation comprises several steps, namely:

- Estimating the impact of non-riparian IAPs in MCAs on surface water yield reduction

- Estimating the impact of IAPs in riparian zones in all catchments on surface water yield reduction

- Estimating the cost of clearing IAPs in mountain catchments

- Estimating the cost of clearing IAPs in riparian zones

- The calculation of the user charge that is required to cover the cost of clearing.

This study presents the initial findings from the first two steps in this investigation with regard to determining the impact of non-riparian IAPs in the MCAs for each WMA, and the impact of riparian IAPs in all catchments for each WMA on the total surface water yield of the country. The final three steps are discussed in a separate paper that appears in this edition of the journal (Blignaut et al., 2007).

The objective of this study was to produce a conservative, i.e. low estimate of SFR due to IAPs. This was intended to limit the final user charge that would be calculated based on the estimated impact on yield.

\section{The impact of IAPs on surface water yield}

Due to the nature of the investigation, the impact of the IAPs had to be executed relatively rapidly and at a strategic level only. Therefore all the information and technology used for the study needed to be readily available and acceptable for a strategic level approach. As a first order identification of the MCAs, this study considered quaternary catchments with a high average MAP, i.e. MAP $>800 \mathrm{~mm} / \mathrm{a}$. These were easy to identify from the WR90 database and would tend to be representative of the MCAs, but may vary in certain areas of the country.

The impact on surface water yield was calculated in four steps:

- Determine the total condensed invaded area of IAPs in the MCAs for four scenarios:

a. Original (1995) recorded level of invasion as per Versfeld et al. (1997)

b. Estimated current (2004) level of invasion taking into account the modelled spread of invasion since 1995

c. Estimated current (2004) level of invasion taking into account the modelled spread of invasion since 1995 less the area already cleared by WfW

d. Future fully invaded condition at $100 \%$ density.

- Determine the average annual streamflow reduction (SFR) in upland areas/MCAs due to IAPs based on the CSIR Curves for SFR by sub-optimal pines (Scott and Smith, 1997) with an average age of 7.5 years. This equates to
$17.8 \%$ of MAR from the equivalent condensed area of alien vegetation.

- Determine the impact that this SFR will have on the 1 in 50 year (98\% assurance) yield from each WMA in terms of yield from major dams, minor dams and average runof-river yield using the Water Situation Assessment Model (WSAM) (Version 3.003).

- Estimate the average riparian area in all catchments for each WMA and determine the impact on yield due to riparian IAPs based on simple estimates of streamflow reduction.

For the purposes of this study, MCAs were assumed to be all quaternary catchments with an average mean annual precipitation (MAP) of above $800 \mathrm{~mm}$. This simple method for identifying the high rainfall catchments (HRCs) was selected as these high MAP catchments are considered as representative of the mountain catchment areas. Therefore, while the invaded area and SFRs were calculated for all quaternary catchments in the country, the impact that this has had on the yield was only calculated for the SFR due to alien vegetation in these high-MAP catchments. The high-MAP catchments of the country, as well as the location of the major dams are shown in Fig. 1. In total there are 397 quaternary catchments with an average MAP of above $800 \mathrm{~mm}$ in South Africa and a further 51 in Lesotho and Swaziland. This represents just under $10 \%$ of the land area of South Africa, but accounts for $50 \%$ of the mean annual runoff (MAR).

To include only those quaternary catchments with an MAP of more than $800 \mathrm{~mm}$ has its shortcomings. A number of the mountain catchments listed in the original Department of Agricultural Technical Services Report (1961) occur in dry areas where the average MAP for the total catchment is below $800 \mathrm{~mm}$, but the MAP in the mountainous part is much higher. This means that the runoff from those mountains contributes the bulk of the runoff in the catchment, but for the purposes of the strategy they are not recognised as MCAs. Some examples are the Swartberg, large parts of the Langeberg, Cederberg and Groot Winterhoek mountains in the Western Cape. In the 
Eastern Cape the Winterhoek range is not recognised as an MCA while these areas contribute the bulk of the streamflow in the downstream rivers.

\section{Level of invasion under present and future scenarios}

The original area of invasive alien vegetation for each quaternary catchment was obtained from the WSAM database, which had in turn been based on the estimated level of invasion by Versfeld et al. (1997). This area of invasion was in terms of the condensed area equivalent to $100 \%$ invasion. The total invaded area was estimated by applying Versfeld's calculated average density for the relevant tertiary catchment.

The current condensed area of invasive alien vegetation was estimated by applying a logistic-curve spreading model to the original Versfeld condensed areas for the period 1995 to 2004. The curve was of the form:

$$
A(t)=\frac{A_{0} \cdot M \cdot e^{r . t}}{M-A_{0}+A_{0} \cdot e^{r . t}}
$$

where:

$$
\begin{array}{ll}
r & =\text { the intrinsic rate of spread }(\%) \\
A(t) & =\text { the condensed area of invasion at time } \mathrm{t}\left(\mathrm{km}^{2}\right) \\
A_{0} & =\text { the condensed area of invasion at } \mathrm{t}=0\left(\mathrm{~km}^{2}\right) \\
M & =\text { the maximum area of invasion }\left(\mathrm{km}^{2}\right) \\
t & =\text { the time interval (years) }
\end{array}
$$

Three different intrinsic rates of spread $(r)$ are used. A high intrinsic rate of spread $(r=17.0 \%)$ was applied to catchments with an average MAP of above $1000 \mathrm{~mm}$, a medium rate $(r=$ $10.5 \%$ ) for catchments with an average MAP of between $800 \mathrm{~mm}$ and $1000 \mathrm{~mm}$, and a slow rate $(r=8.5 \%)$ for catchments with an average MAP of below $800 \mathrm{~mm}$. The resulting models of spread for high-, medium- and slow-growth areas are shown in Fig. 2. The minimum level of invasion was assumed to be $1 \%$, while the maximum level of invasion was assumed to be $87.5 \%$ of the untransformed area.

The spreading model was applied to the original condensed area of invasion in order to determine the current condensed area of invasion before clearing. The average Versfeld tertiary catchment densities were used to estimate the total invaded area.

Data on the areas cleared by WfW before 2003 had been gathered from the various provinces and combined to give the total and condensed cleared areas for each quaternary catchment as part of the external evaluation of the WfW Programme. These areas were subtracted from the estimated current invaded area before clearing to give the estimated current condensed area and total invaded area after clearing.

The future maximum invadable area was assumed to be $87.5 \%$ of the 'untransformed' area. This was in recognition of the fact that the invasion level would never reach $100 \%$ of the 'untransformed' area. The 'untransformed' area was considered to the area available for invasion, i.e. it was not already utilised, or transformed to some other land use type that would exclude the invasion by IAPS. The 'untransformed' area was estimated by subtracting the area of indigenous and plantation forests, irrigated land, dry-land sugar cane and urban areas from the total catchment area. The data on land use was obtained from the WSAM database in which a noticeable omission is the area of dry-land farming. However, it was decided that, as the objective was to focus on the high MAP catchments, which were generally located in mountainous areas, the omission of dry-land farming area would not have a significant impact on the results. The most

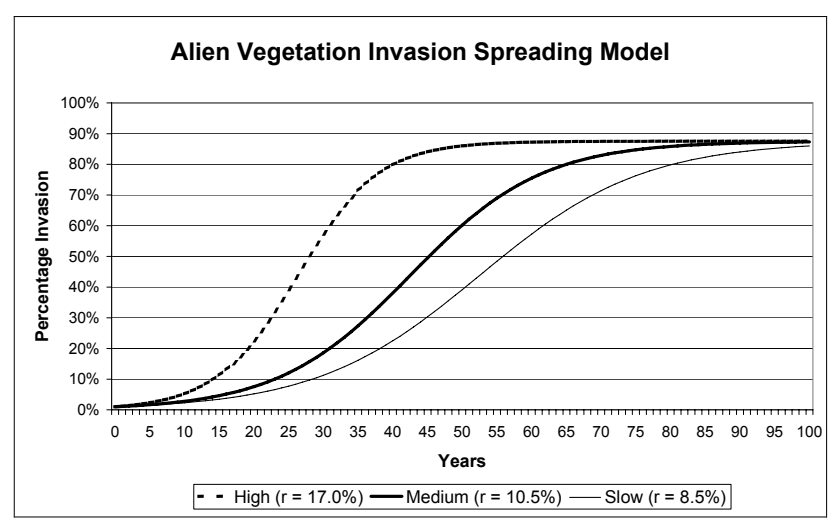

Figure 2

Spreading model for invasive alien vegetation

significant land use in these areas would be forestry and this was relatively well captured in WSAM. It was assumed that the maximum invasion would be at $100 \%$ density.

In all three cases the upland invaded areas were estimated by reducing the total invaded area by $0.75 \%$ to account for the riparian areas. This was based on calculations for the whole country that showed on average $0.5 \%$ of the area of each catchment could be classified as riparian along perennial rivers in the catchment and $0.25 \%$ along non-perennial. The riparian area was assumed to be all land within an average $41.5 \mathrm{~m}$ strip on either side of perennial rivers and $21.5 \mathrm{~m}$ strip along non-perennial rivers.

\section{Streamflow reduction in the high rainfall areas}

Given the limited timeframe for the study, the streamflow reduction (SFR) due to IAPs was calculated based on the CSIR curves (Scott et al., 1997) and using a single 'representative' plant type. The CSIR curves are based on empirical data from fully forested catchments in high rainfall areas. The curve for sub-optimal pines was used with an average age of 7.5 years, i.e. an average fire cycle of 15 years. This equates to an average annual SFR of $17.8 \%$ of the MAR from the equivalent condensed area $(100 \%$ density) and was chosen because it was simple to apply and is considered to be conservative, i.e. it would result in lower SFR than other approaches.

In comparison the equivalent SFR according to the more recent biomass curves (Le Maitre and Görgens, 2001) for tall trees of an average age of 7.5 years would be between $20 \%$, based on a long lag curve, and $46 \%$, based on a short lag curve. Both the CSIR curves and the biomass curves, however, result in significantly less SFR due to alien vegetation than the original CSIR curves (Le Maitre et al., 1996), which were used by Versfeld, in the NWRS and in the WSAM model. These earlier curves determine the SFR as an absolute number (in $\mathrm{mm}$ ) based on average biomass, rather than as a percentage of the MAR. For example, the average annual SFR for a tall tree of 7.5 years in a non-optimal area using the original CSIR curves (Le Maitre et al., 1996) is approximately $248 \mathrm{~mm}$.

\section{Impact on total surface water yield}

The yield impact of IAPs was calculated using WSAM. This model was used because it had been configured for the entire country and took into account the cascading effect that a reduction in streamflow in an upstream catchment would have on any dams located in downstream catchments. WSAM is 


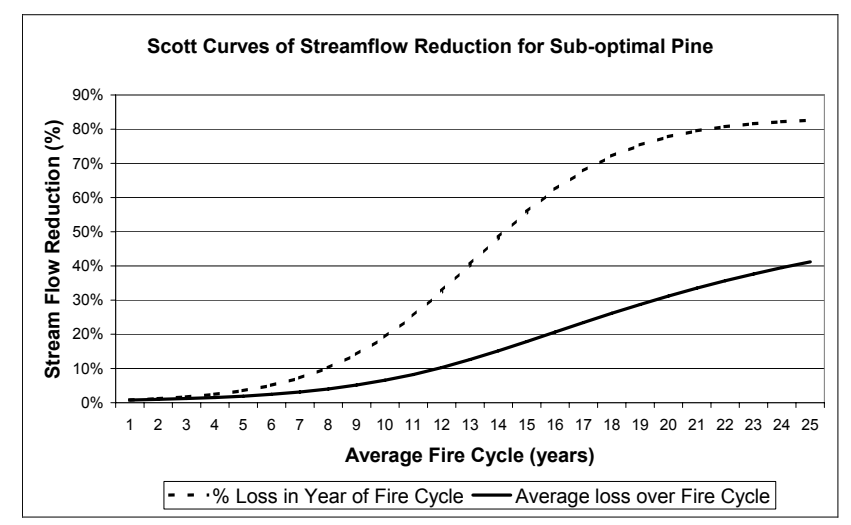

Figure 3

CSIR curves of streamflow reduction for sub-optimal pine

a cascading surface water yield balance model configured at quaternary catchment scale and incorporating relatively up-todate information on land use and water resource infrastructure for the whole of South Africa. The 1:50 year yields that 'drive' the model were derived externally to the WSAM process, based on quaternary scale monthly streamflows derived from the socalled WR90 water resource situation assessment for South Africa (Midgley et al., 1994).

The yield from dams is calculated based on the generalised storage-draft-frequency (SDF) curve (DWAF, 2003):

$$
Y=\left(1-A^{\left(S+\left(\frac{\operatorname{Ln}\left(1-\frac{y_{0}}{C}\right)}{\operatorname{Ln}(A)}\right)\right.}\right) * C+(1-C) *(1-B)^{S}
$$

where:

$$
\begin{aligned}
& Y=\text { yield as a proportion of MAR } \\
& S=\text { storage as a proportion of MAR } \\
& A=\text { coefficient describing the storage-yield curve } \\
& B=\text { coefficient describing the storage-yield curve } \\
& C=\text { coefficient describing the storage-yield curve } \\
& y_{0}=\text { Y intercept on the storage-yield curve }
\end{aligned}
$$

The SDF coefficients were derived for all quaternary catchments based on 100070 -year stochastic sequences and replace the original WR90 SDF curves (Van Rooyen and Swart, 2003). The yield from minor dams was calculated in terms of the incremental MAR from the catchment in which the dams were located. The yield for major dams, however, was calculated based on the cumulative MAR at the catchment outlet taking into account the contribution from upstream dams. The yields for both major and minor dams were calculated for a $98 \%$ level of assurance, but did not take into account losses due to evaporation, river losses or the silting up of dams.

The average annual run-of-river yield was calculated for catchments without significant storage. The run-of-river yield is calculated as a proportion of the MAR calculated from the stochastic sequences mentioned earlier and represents the sum of the monthly flows that occurs once in fifty years (DWAF, 2003). Determining the impact of alien vegetation on the run-of-river yield can be considered a proxy for determining the impact on the ecological reserve as well as that part of the human social reserve used by rural communities abstracting water straight from the water resource. In order to calculate the yield balance in WSAM, the run-of-river yield is separated into dry and wet seasons to correspond with changes in irrigation demand. For the purposes of this study, however, the average annual run-of-river yield was used to determine the impact of IAPs on the total yield.
In order to determine the impact of alien vegetation on the yield, the parameter variable for the natural MAR (vMARi) in the selected catchments (i.e. with an MAP above $800 \mathrm{~mm}$ ) was reduced by the corresponding SFR for the specific invasion scenario. This was done by importing a change list to WSAM and is based on the assumption that upland alien vegetation has the first impact on the incremental MAR in a catchment. To avoid double counting the area invaded by alien vegetation parameter (aAAAi) in the model was set to zero for all catchments. The model was then run based on the default 1995 settings and the following output variables were extracted for each quaternary catchment:

- $\quad$ yYMIo = yield from minor dams

- gYCTo $=$ gross yield from major dams before net evaporation

- $\quad \mathrm{dVRVo}=$ average annual run-of-river yield: disturbed flow.

The yields from individual quaternary catchments were then compared to the yields calculated based on the unimpacted natural MAR and summed by WMA to determine the impact that invasive alien vegetation in the high MAP catchments of the country has on the total yield from each WMA.

\section{The impact of IAPs in the riparian zone}

The area that riparian zones cover in each WMA was estimated in terms of a percentage total area of the WMA. For perennial rivers it was assumed that the riparian zone represents $0.5 \%$ of the total area. For non-perennial rivers it was assumed to be $0.25 \%$ of the area. The river lengths in South Africa are approximately $153800 \mathrm{~km}$; if these river lengths are compared to the estimated riparian areas based on the above percentages, then the average riparian zone would be $83 \mathrm{~m}$ wide $(41.5 \mathrm{~m}$ on each side of the river), in the case of perennial rivers and $41 \mathrm{~m}$ wide (20.5 $\mathrm{m}$ on each side of the river) for non-perennial rivers. To verify these assumptions, data from surveys done on sections of rivers in the Western Cape during the period 1996 to 1998 were analysed. Both main course and tributaries were included in the surveys, but no differentiation was made between perennial and non-perennial rivers. The average riparian strip in these studies was found to be around $60 \mathrm{~m}$, with a maximum of $1.5 \mathrm{~km}$ and a minimum of $5 \mathrm{~m}$. Hence the estimation of the riparian area as a percentage of the total area gives relatively consistent results.

In this study the impact of IAPs in the riparian zone was assumed to be similar to that of water losses from a leaking pipe. This was based on the assumption that rivers act as conduits for water distribution in South Africa. It was therefore assumed that during low-flow periods the reduction in yield, as a result of IAPs, could be assumed to be equal to the SFR. This is based on the assumption that IAPs in the riparian zones never come under water stress, especially in the case of perennial rivers. However, during high-flow periods and more specifically during floods, this is not necessarily the case. It was therefore assumed that only $75 \%$ of the total estimated SFR could be taken to be equal to the reduction in yield.

In order to maintain the conservative nature of the approach adopted in the calculations for the impact of non-riparian IAPs, the assumed annual SFR was based on $1000 \mathrm{~m}^{3} / \mathrm{ha}$ and 3000 $\mathrm{m}^{3} / \mathrm{ha}$ for the non-perennial and perennial rivers respectively. This represents a low estimate of the SFR for riparian IAPs equivalent to an average SFR of $100 \mathrm{~mm}$ and $300 \mathrm{~mm}$ respectively. For comparison some figures gathered from the experimental clearing of both riparian and non-riparian IAPs are shown in Table 1. 


\section{Results}

\section{Invaded area}

The total invaded area and equivalent $100 \%$ density condensed areas of invasive alien vegetation for the MCAs are summarised in Table 2, which also shows the invaded and condensed areas as

\section{TABLE 1}

Impacts of IAPs on runoff in riparian versus non-riparian areas

\begin{tabular}{|l|l|c|}
\hline Study area & Treatment & $\begin{array}{c}\mathbf{1}^{\text {st }} \\
\text { in strear increase } \\
\text { after treatment } \\
\left(\mathbf{m}^{3} / \mathbf{h a}\right)\end{array}$ \\
\hline \multirow{2}{*}{ Witklip (Mpumalanga) } & Clear riparian scrub \& pines & 7965 \\
\cline { 2 - 3 } & Clear non-riparian pines & 4045 \\
\hline Biesiesvlei (Western Cape) & Clear riparian pines & 11505 \\
\hline
\end{tabular}

Source: Görgens and Van Wilgen (2004)

TABLE 2

Area invaded by non-riparian IAPs in the MCAs

\begin{tabular}{|l|c|c|c|c|c|}
\hline \multirow{2}{*}{ Invasion scenario } & \multicolumn{2}{|c|}{ Invaded area } & \multicolumn{2}{c|}{ Condensed area } & Avg. density \\
\cline { 2 - 6 } & $\mathbf{k m}^{\mathbf{2}}$ & $\mathbf{( \% )}$ & $\mathbf{k m}^{\mathbf{2}}$ & $\mathbf{( \% )}$ & $\mathbf{( \% )}$ \\
\hline Original & 14688 & 12.6 & 4031 & 3.5 & 27.4 \\
\hline Current (before clearing) & 24486 & 21.0 & 8727 & 7.5 & 35.6 \\
\hline Cleared area & 3974 & 3.4 & 1100 & 0.9 & 27.7 \\
\hline Current (after clearing) & 21450 & 18.4 & 7873 & 6.8 & 36.7 \\
\hline Future & 86643 & 74.4 & 86643 & 74.4 & 100.0 \\
\hline
\end{tabular}

\begin{tabular}{|c|c|c|c|}
\hline \multicolumn{4}{|c|}{$\begin{array}{c}\text { TABLE } 3 \\
\text { Estimated streamflow reduction due to non-riparian } \\
\text { IAPs in the MCAs }\end{array}$} \\
\hline \multirow{2}{*}{ Invasion scenario } & \multicolumn{3}{|c|}{ SFR } \\
\hline & $\left(\mathrm{Mm}^{3} / \mathrm{a}\right)$ & $(\%)$ & $(\mathrm{mm})$ \\
\hline Original & 161 & 0.7 & 40 \\
\hline Current (before clearing) & 360 & 1.6 & 41 \\
\hline Current (after clearing) & 311 & 1.4 & 41 \\
\hline Future & 2886 & 13.0 & 33 \\
\hline
\end{tabular}

\begin{tabular}{|l|c|c|c|}
\hline \multicolumn{4}{|c|}{ TABLE 4 } \\
\hline Study & $\begin{array}{c}\text { Demand } \\
\text { scenario }\end{array}$ & $\begin{array}{c}\text { Afforestation- } \\
\text { related streamflow } \\
\text { reduction } \\
\left.\text { (million } \text { m }^{3} / \mathbf{a}\right)\end{array}$ & $\begin{array}{c}\text { Afforestation- } \\
\text { related streamflow } \\
\text { reduction } \\
\left.\text { (million } \mathbf{m}^{3} / \mathbf{a}\right)\end{array}$ \\
\hline DWAF (1986) & $1990 \sim$ & 1427 & 114 \\
\hline Van der Zel (1996) & 1995 & 396 & 28 \\
\hline CSIR (1998) & $1993 \& 1996$ & 1417 & 99 \\
\hline LHA (1998a) & $1997 \sim$ & 500 & 35 \\
\hline LHA (1998b) & $1997 \sim$ & $700-800$ & $49-56$ \\
\hline
\end{tabular}

Source: Görgens (2003) a percentage of the total area of the selected quaternary catchments in South Africa.

\section{Streamflow reduction}

The total SFR due to IAPs in the MCAs for the different invasion scenarios is summarised in Table 3, which shows the SFR as a percentage of the total MAR from the selected catchments.

The average unit SFR varies from $33 \mathrm{~mm}$ to $41 \mathrm{~mm}$. This is quite low considering that these are the high MAP catchments and is most likely due to the conservative nature of the $17.8 \%$ streamflow reduction used. In comparison the average unit streamflow gain as a result of the clearing of IAPs calculated as part of the External Evaluation of the WfW Programme, ranged between $37 \mathrm{~mm}$ and $54 \mathrm{~mm}$. This estimation was based on the higher biomass-based SFR curves, which produced larger SFR estimates. Other estimates for the average SFR of afforestation are given in Table 4.

More recently SFR tables have been developed for a range of plant types for all quaternary catchments in South Africa using ACRU (Gush et al., 2002). These tables are used to estimate the SFR due to afforestation for the purposes of calculating a water-use charge for streamflow reduction activities (SFRA). According to these tables the mean average SFR for pines in medium soil depth across the country is $55 \mathrm{~mm} / \mathrm{a}$. From the above comparison it is clear that the estimated SFR of IAPs made in this study of between $37 \mathrm{~mm} / \mathrm{a}$ and 54 $\mathrm{mm} / \mathrm{a}$ is significantly lower than from previous studies. This is consistent with the objective of the study to give a conservative, i.e. low, estimate of the impact of IAPs on the available yield to the country.

\section{Impact on yield}

The impact of non-riparian IAPs in the MCAs on the total MAR and yield of the country are summarised in Table 5 in terms of both the absolute impact and the percentage of the uninvaded MAR or yield.

The impact on the yield varies significantly between water management areas. Table 6 shows the impact of the estimated current (after clearing) and future level of invasion on the MAR and yields in each WMA.

Table 7 shows the reduction in yield due to

\begin{tabular}{|c|c|c|c|c|c|c|c|c|}
\hline & MAR and $y$ & redu & $\begin{array}{r}\text { TABL } \\
\text { on due to }\end{array}$ & ripari & IAPs in th & ICAs & & \\
\hline Invasion scenario & Reductic & MAR & $\begin{array}{l}\text { Reduction } \\
\text { mino }\end{array}$ & $\begin{array}{l}\text { jield of } \\
\text { ns }\end{array}$ & $\begin{array}{l}\text { Reduction } \\
\text { majo }\end{array}$ & $\begin{array}{l}\text { jield of } \\
\text { ns }\end{array}$ & $\begin{array}{r}\text { Reduction } \\
\text { river }\end{array}$ & $\begin{array}{l}\text { un-of- } \\
d\end{array}$ \\
\hline & $\left(10^{6} \mathrm{~m}^{3} / \mathrm{a}\right)$ & (\%) & $\left(10^{6} \mathrm{~m}^{3} / \mathrm{a}\right)$ & (\%) & $\left(10^{6} \mathrm{~m}^{3} / \mathrm{a}\right)$ & $(\%)$ & $\left(10^{6} \mathrm{~m}^{3} / \mathrm{a}\right)$ & $(\%)$ \\
\hline Original & 160 & 0.4 & 2 & 0.2 & 30 & 0.2 & 56 & 0.6 \\
\hline Current (before clearing) & 360 & 0.8 & 4 & 0.3 & 67 & 0.5 & 124 & 1.2 \\
\hline Current (after clearing) & 319 & 0.7 & 3 & 0.3 & 60 & 0.5 & 109 & 1.1 \\
\hline Future & 2887 & 6.6 & 24 & 2.0 & 511 & 4.0 & 875 & 8.6 \\
\hline
\end{tabular}




\begin{tabular}{|c|c|c|c|c|c|c|c|c|}
\hline \multicolumn{9}{|c|}{$\begin{array}{c}\text { TABLE } 6 \\
\text { Reduction in total MAR and yield due to non-riparian IAPs in the MCAs }\end{array}$} \\
\hline \multirow[t]{3}{*}{ WMA } & \multicolumn{2}{|c|}{ Incremental MAR } & \multicolumn{2}{|c|}{$\begin{array}{l}\begin{array}{c}\text { Yield from minor } \\
\text { dams }\end{array} \\
\end{array}$} & \multicolumn{2}{|c|}{$\begin{array}{c}\begin{array}{c}\text { Yield from major } \\
\text { dams }\end{array} \\
\end{array}$} & \multicolumn{2}{|c|}{ RoR yield: Disturbed } \\
\hline & Current & Future & Current & Future & Current & Future & Current & Future \\
\hline & $\left(10^{6} \mathrm{~m}^{3} / \mathrm{a}\right)$ & $\left(10^{6} \mathrm{~m}^{3} / \mathrm{a}\right)$ & $\left(10^{6} \mathrm{~m}^{3} / \mathrm{a}\right)$ & $\left(10^{6} \mathrm{~m}^{3} / \mathrm{a}\right)$ & $\left(10^{6} \mathrm{~m}^{3} / \mathrm{a}\right)$ & $\left(10^{6} \mathrm{~m}^{3} / \mathrm{a}\right)$ & $\left(10^{6} \mathrm{~m}^{3} / \mathrm{a}\right)$ & $\left(10^{6} \mathrm{~m}^{3} / \mathrm{a}\right)$ \\
\hline Berg & 19 & 96 & 0.3 & 1.6 & 3.5 & 12.1 & 9.5 & 43.6 \\
\hline Breede & 29 & 167 & 0.3 & 5.0 & 11.0 & 37.0 & 12.5 & 74.7 \\
\hline Crocodile (West) and Marico & 0 & 0 & 0.0 & 0.0 & 0.0 & 0.0 & 0.0 & 0.0 \\
\hline Fish to Tsitsikama & 9 & 50 & 0.0 & 0.4 & 0.1 & 1.3 & 3.7 & 20.6 \\
\hline Gouritz & 16 & 53 & 0.0 & 0.2 & 0.3 & 1.4 & 6.1 & 20.3 \\
\hline Inkomati & 66 & 207 & 0.5 & 1.2 & 9.3 & 43.4 & 25.7 & 76.9 \\
\hline Limpopo & 1 & 6 & 0.0 & 0.0 & 0.1 & 1.4 & 0.0 & 0.5 \\
\hline Lower Orange & 0 & 0 & 0.0 & 0.0 & 0.0 & 0.0 & 0.0 & 0.0 \\
\hline Lower Vaal & 0 & 0 & 0.0 & 0.0 & 0.0 & 0.1 & 0.0 & 0.0 \\
\hline Luvuvhu and Letaba & 14 & 73 & 0.7 & 2.0 & 3.3 & 14.6 & 4.0 & 19.6 \\
\hline Middle Vaal & 0 & 0 & 0.0 & 0.0 & 0.0 & 0.0 & 0.0 & 0.0 \\
\hline Mvoti to Umzimkulu & 47 & 569 & 0.6 & 6.0 & 1.9 & 37.8 & 13.9 & 186.2 \\
\hline Mzimvubu to Keiskamma & 15 & 665 & 0.0 & 0.7 & 3.5 & 26.2 & 3.8 & 149.1 \\
\hline Olifants & 25 & 78 & 0.1 & 0.4 & 7.4 & 16.4 & 10.9 & 28.4 \\
\hline Olifants/Doorn & 2 & 13 & 0.0 & 0.2 & 0.3 & 3.0 & 0.7 & 4.7 \\
\hline Thukela & 20 & 416 & 0.4 & 4.3 & 3.8 & 76.2 & 5.6 & 115.0 \\
\hline Upper Orange & 0 & 15 & 0.0 & 0.0 & 0.0 & 95.3 & 0.0 & 4.5 \\
\hline Vaal & 1 & 19 & 0.0 & 0.0 & 0.7 & 7.3 & 0.1 & 2.2 \\
\hline Usutu to Mhlathuze & 55 & 459 & 0.3 & 1.5 & 14.4 & 137.4 & 12.5 & 129.4 \\
\hline TOTAL & 319 & 2887 & 3 & 24 & 60 & 511 & 109 & 875 \\
\hline
\end{tabular}

\begin{tabular}{|c|c|c|c|c|c|c|}
\hline \multicolumn{7}{|c|}{$\begin{array}{c}\text { TABLE } 7 \\
\text { Impact of invasive alien tree species in riparia }\end{array}$} \\
\hline \multirow[t]{3}{*}{ WMA } & \multirow[t]{2}{*}{$\begin{array}{l}\text { Total length } \\
\text { of rivers }\end{array}$} & \multirow[t]{2}{*}{$\begin{array}{l}\text { Riparian area } \\
\text { for perennial } \\
\text { rivers }\end{array}$} & \multicolumn{2}{|c|}{$\begin{array}{l}\text { Condensed invaded ripar- } \\
\text { ian area for perennial and } \\
\text { non-perennial rivers }\end{array}$} & \multicolumn{2}{|c|}{$\begin{array}{l}\text { Reduction in yield due to } \\
\text { IAPs in perennial and non } \\
\text { perennial riparian areas }\end{array}$} \\
\hline & & & Current & Future & Current & Future \\
\hline & (km) & $\left(\mathbf{k m}^{2}\right)$ & $\left(\mathrm{km}^{2}\right)$ & $\left(\mathrm{km}^{2}\right)$ & $\left(10^{6} \mathrm{~m}^{3}\right)$ & $\left(10^{6} \mathrm{~m}^{3}\right)$ \\
\hline Berg & 1884 & 245 & 45 & 78 & 5 & 9 \\
\hline Breede & 3179 & 677 & 83 & 144 & 11 & 20 \\
\hline Crocodile (West) and Marico & 5027 & 228 & 81 & 281 & 15 & 51 \\
\hline Fish to Tsitsikamma & 15806 & 340 & 412 & 717 & 57 & 100 \\
\hline Gouritz & 8284 & 214 & 114 & 392 & 17 & 58 \\
\hline Inkomati & 3908 & 208 & 67 & 232 & 13 & 45 \\
\hline Limpopo & 5424 & 283 & 93 & 320 & 18 & 61 \\
\hline Lower Orange & 23704 & 240 & 66 & 755 & 8 & 88 \\
\hline Lower Vaal & 6562 & 100 & 24 & 279 & 3 & 34 \\
\hline Luvuvhu and Letaba & 2787 & 142 & 14 & 163 & 3 & 31 \\
\hline Middle Vaal & 5874 & 243 & 183 & 318 & 32 & 56 \\
\hline Mvoti to Umzimkulu & 11935 & 958 & 491 & 853 & 109 & 190 \\
\hline Mzimvubu to Keiskamma & 5419 & 353 & 202 & 351 & 42 & 73 \\
\hline Olifants & 6915 & 418 & 249 & 433 & 50 & 87 \\
\hline Olifants/Doorn & 7869 & 163 & 27 & 306 & 4 & 44 \\
\hline Thukela & 4378 & 327 & 174 & 302 & 38 & 65 \\
\hline Upper Orange & 11574 & 360 & 50 & 571 & 8 & 90 \\
\hline Upper Vaal & 7835 & 549 & 152 & 524 & 32 & 111 \\
\hline Usutu to Mhlatuze & 7132 & 507 & 277 & 481 & 59 & 103 \\
\hline Total & 145494 & 5726 & 2804 & 7501 & 523 & 1314 \\
\hline
\end{tabular}




\begin{tabular}{|l|c|c|c|c|}
\hline \multicolumn{5}{|c|}{ Total reduction in yield due to IAPs (MCA plus riparian areas) } \\
\hline \multirow{2}{*}{ WMA } & Current levels of infestation & \multicolumn{2}{c|}{ Future levels of infestation } \\
\cline { 2 - 5 } & $\mathbf{M m}^{3}$ & $\begin{array}{c}\text { \% of registered } \\
\text { water use }\end{array}$ & $\mathbf{M m}^{3}$ & $\begin{array}{c}\text { \% of registered } \\
\text { water use }\end{array}$ \\
\hline Berg & 19 & 2.6 & 66 & 9.2 \\
\hline Breede & 35 & 5.3 & 136 & 20.7 \\
\hline Crocodile (West) and Marico & 15 & 1.7 & 51 & 5.8 \\
\hline Fish to Tsitsikamma & 61 & 4.4 & 121 & 8.7 \\
\hline Gouritz & 23 & 5.8 & 79 & 20.1 \\
\hline Inkomati & 49 & 3.7 & 166 & 12.5 \\
\hline Limpopo & 18 & 2.9 & 63 & 10.1 \\
\hline Lower Orange & 8 & 0.7 & 88 & 7.8 \\
\hline Lower Vaal & 3 & 0.4 & 34 & 4.2 \\
\hline Luvuvhu and Letaba & 11 & 2.1 & 67 & 13.2 \\
\hline Middle Vaal & 32 & 5.3 & 56 & 9.2 \\
\hline Mvoti to Umzimkulu & 126 & 14.8 & 420 & 49.3 \\
\hline Mzimvubu to Keiskamma & 49 & 5.6 & 249 & 28.4 \\
\hline Olifants & 69 & 6.8 & 133 & 13.1 \\
\hline Olifants-Doorn & 5 & 1.5 & 52 & 16.1 \\
\hline Thukela & 48 & 12.1 & 261 & 66.6 \\
\hline Upper Orange & 8 & 0.5 & 190 & 13.1 \\
\hline Upper Vaal & 33 & 1.8 & 121 & 6.6 \\
\hline Usutu to Mhlatuze & 86 & 7.6 & 371 & 32.7 \\
\hline South Africa & 695 & 4.1 & 2724 & 16.1 \\
\hline
\end{tabular}

IAPs in the riparian zones in all catchments. The variation in the impact between WMAs is not as significant in this case as the impact of riparian IAPs is calculated for the whole WMA and not only as a result of the IAPs in the MCAs as is the case in Table 6.

Table 8 shows the total estimated impact of IAPs in both the MCAs and the riparian areas in terms of the potential reduction in yield. To put the impact in context, it is also expressed in terms of the percentage of total registered water use in each WMA.

\section{Conclusions}

Based on the above results, the following conclusions can be drawn:

- The SFR due to IAPs calculated in this study using the CSIR curves is substantially lower than similar estimates via the biomass-based SFR curves, the original absolute value CSIR curves, and the Gush Tables. This may have the effect of under-estimating the true IAP-related impact on runoff and yield, but is consistent with the intended conservative nature of the study.

- Despite this, non-riparian IAPs in the high MAP catchments of South Africa are estimated to have a sizeable impact on the total yield of the country, particularly in terms of the yield from major dams and run-of-river estimates. The reduction in the yield from major dams is estimated at $60 \mathrm{x}$ $10^{6} \mathrm{~m}^{3} / \mathrm{a}(0.5 \%)$, while the reduction in the run-of-river yield is estimated to be $109 \times 10^{6} \mathrm{~m}^{3} / \mathrm{a}(1 \%)$.

- While the impact on the yield from minor dams does not appear to be as significant, this may well be due to the limited information available on minor dams across the country as well as the fact that there are generally fewer minor dams in the high MAP catchments.

- If the spread of alien vegetation is not managed and a state of full invasion is reached, this will have a very marked impact on the available yield. According to this scenario, non-riparian IAPs in the high MAP catchments will reduce the available yield from major dams in the country by some $4.0 \%\left(511 \times 10^{6} \mathrm{~m}^{3} / \mathrm{a}\right)$ and the average run-of-river yield by $8.6 \%\left(875 \times 10^{6} \mathrm{~m}^{3} / \mathrm{a}\right)$.

- The impact on the yield varies noticeably between WMAs. This is due to the differences in runoff, which in turn is related to the number of high-MAP catchments in the WMA, as well as the varying degree of invasion in these high-MAP catchments. This should be taken into consideration when developing a pricing strategy and may result in different user charges being applied in the different WMAs.

- The impact of riparian IAPs is estimated to be highly significant. The estimated current level of impact is $523 \times 10^{6}$ $\mathrm{m}^{3} / \mathrm{a}$ and this is predicted to be as high as $1314 \times 10^{6} \mathrm{~m}^{3} / \mathrm{a}$ if allowed to reach a future fully invaded state.

- The total combined impact on yield due to riparian IAPs in all catchments and non-riparian IAPs in the MCAs is estimated to be $695 \times 10^{6} \mathrm{~m}^{3} / \mathrm{a}$ under current levels of invasion and is likely to increase to $2724 \times 10^{6} \mathrm{~m}^{3} /$ a under a fully invaded future scenario. This represents $4 \%$ and $16 \%$ of the total volume of currently registered water use in the country.

The results from this study will be used to guide the quantification of a management charge for the clearing of IAPs in South Africa. The potential impact on yield is only one of a number of factors that need to be considered. The approach that will be adopted for determining the charge is outlined in a separate paper in this edition of the journal (Blignaut et al., 2007).

\section{References}

BLIGNAUT JN, MARAIS C and TURPIE JK (2007) Determining a charge for the clearing of invasive alien plant species (IAPs) to augment water supply in South Africa. Water SA 33 (1) 27-34. 
CULLIS J, GÖRGENS A and MARAIS C (2005) A strategic study of the impact of invasive alien vegetation in the mountain catchment areas and riparian zones of South Africa on total surface water yield. Proc. S. Afr. Hydrol. Symp. (SANCHIAS) 5 to 7 September 2005, Midrand, South Africa.

DEPARTMENT OF WATER AFFAIRS AND FORESTRY (2003) Water Situation Assessment Model, Version 3.0: Training Manual. DWAF, Pretoria

DEPARTMENT OF WATER AFFAIRS AND FORESTRY (1998) Quantification of Streamflow Due to Afforestation in South Africa: A Review Study. Report by Ninham Shand to DWAF, Report No. RSA/00/0398. DWAF, Pretoria

DEPARTMENT OF AGRICULTURAL TECHNICAL SERVICES (1961) Report of the Interdepartmental Committee on the Conservation of Mountain Catchments in South Africa ('The Ross Report') Pretoria, South Africa.

GÖRGENS A and VAN WILGEN BW (2004) Invasive alien plants and water resources in South Africa: Current understanding, predictive ability and research challenges. S. Afr. J. Sci. 100 27-33.

GÖRGENS A (2003) In search of a protocol for the quantification of streamflow reduction (SFRs) due to commercial afforestation in South Africa. Proc. $11^{\text {th }}$ S. Afr. Nat. Hydrol. Symp. 3 to 5 September 2001, Port Elizabeth, South Africa.

GUSH M, SCOTT D, JEWITT G, SCHULTZE R, LUMSDEN T, HALLOWES L and GÖRGENS A (2002) Estimation of Streamflow Reductions Resulting from Commercial Afforestation in South Africa. WRC Report TT 173/02. Water Research Commission, Pretoria.

LE MAITRE D, VAN WILGEN BW, CHAPMAN RA and McKELLY DH (1996) Invasive plants in the Western Cape, South Africa: Modeling the consequences of a lack of management. J. Appl. Ecol. 33 161-172.
LE MAITRE D and GÖRGENS A. (2001) Potential impacts of invasive alien plants on reservoir yields in South Africa. Proc. 10 $0^{\text {th }}$ S. Afr. Natl. Hydrol. Symp. 26 to 28 September 2001, Pietermaritzburg, South Africa.

LHA (1998a) Comparative Differences between Streamflow Reduction of Dry-Land Agriculture Crops and Commercial Forestry. Technical Note (1651/98) by LHA Management Consultants, Pretoria.

LHA (1998b) Presentation to the DWAF Workshop on Streamflow Reduction Impacts due to Commercial Afforestation. 3 June 1998, Pretoria, South Africa.

MIDGLEY DC, PITMAN WV and MIDDLETON BJ (1994) Surface Water Resources of South Africa 1990. WRC Report No. 298/4.1/94. Water Research Commission, Pretoria, South Africa.

SCOTT DF and SMITH RE (1997) Preliminary empirical models to predict reductions in total and low flows resulting from afforestation. Water SA 23 (2) 187-200.

VERSFELD DB, LE MAITRE DC and CHAPMAN RA (1998) Alien Invading Plants and Water Resources in South Africa: A Preliminary Assessment. WRC Report No. TT 99/98. Water Research Commission, Pretoria, South Africa.

VAN DER ZEL DW (1990) The Afforestation Permit System. Information Leaflet No 1, Department of Environmental Affairs, Pretoria.

VAN ROOYEN PG and SWART HS (2003) Revision of Storage-DraftFrequency Characteristics for the WSAM (based on Median Starting Storages of Major and Minor Dams). DWAF Report No. 14/12/4/2 (Interim Report). Department of Water Affairs and Forestry, South Africa.

VAN WILGEN BW, DE WIT MP, ANDERSON HJ, LE MAITRE DC, KOTZE IM, NDALA S, BROWN B and RAPHOLO MP (2004) Costs and benefits of biological control of invasive alien plants in South Africa: Case studies from South Africa'. S. Afr. J. Sci. 100 $113-122$. 